\title{
LITERATURE REVIEW: PENGARUH RELAKSASI OTOT PROGRESIF TERHADAP KUALITAS TIDUR PADA PASIEN PENYAKIT GINJAL KRONIK YANG MENJALANI HEMODIALISIS
}

\author{
LITERATURE REVIEW: THE EFFECT OF \\ PROGRESSIVE MUSCLE RELAXATION ON SLEEP \\ QUALITY IN CHRONIC KIDNEY DISEASE PATIENTS \\ THROUGH HEMODIAL YSIS
}

\author{
Virgianti Nur Faridah ${ }^{1,2}$, Trijati Puspita Lestari², Dedy Dwi Rizkyawan ${ }^{3}$ \\ ${ }^{1}$ Prodi Doktor Keperawatan, Fakultas Keperawatan, Universitas Airlangga \\ ${ }^{2}$ Departemen Keperawatan Medikal Bedah, Fakultas Ilmu Kesehatan, Universitas Muhammadiyah \\ Lamongan, Indonesia \\ ${ }^{3}$ Mahasiswa Prodi S1 Keperawatan, Fakultas Ilmu Kesehatan, Universitas Muhammadiyah \\ Lamongan, Indonesia
}

\begin{abstract}
ABSTRAK
Pasien PGK merasakan kelelahan setelah melakukan hemodialisis, sehingga pasien mengalami gangguan dalam bekerja dan kegiatan sehari-hari. Pasien dengan penyakit PGK yang sudah mencapai derajat 5 atau tahap akhir akan mengalami gangguan, tidak hanya terbatas pada sistem ginjal, namun tubuh lain juga dapat dipengaruhi yang dapat menyebabkan penurunan status kesehatan dan kualitas tidur. Tujuan penelitian ini adalah untuk mengkaji dengan literature review pengaruh teknik relaksasi otot progresif terhadap kualitas tidur pasien penyakit ginjal kronik. Literatur Review dengan menggunakan 4 database (Scopus, Science Direct, Google Scholar, dan Pubmed ) untuk mencari jurnal dengan kriteria jurnal yang terbit tahun 2015-2020, fulltext, jurnal yang sesuai dengan topik, terdapat ISSN, volume, dan nomer jurnal, merupakan jurnal intervensi relaksasi otot progresif pada pasien penyakit ginjal kronik. Setelah mengumpulkan data, semua data diseleksi sesuai dengan kriteria inklusi dan eksklusi, kemudian diseleksi studi dengan menggunakan flow diagram PRISMA 2009. Berdasarkan 10 artikel yang terpilih didapatkan hasil terapi relaksasi otot progresif dapat meningkatkan kualitas tidur pasien penyakit ginjal kronik. Berdasarkan 10 artikel terpilih sesuai kriteria inklusi yaitu terapi relaksasi otot progresif dapat diterapkan pada pasien penykit ginjal kronik untuk meningkatkan kualitas tidur pasien.
\end{abstract}

Kata Kunci: terapi relaksasi otot progresif, kualitas tidur

\section{ABSTRACT}

Patients with CKD disease that has reached grade 5 or the final stage will experience disturbances, not only limited to the kidney system, but other bodies can also be affected which can cause a decrease in health status and sleep quality. The purpose of this study was to examine with literature review the effect of progressive muscle relaxation techniques on the sleep quality of patients with chronic kidney disease. Regular Review using 4 databases (Scopus, Science Direct, Google Scholar, and PubMed) to search for articles with criteria for articles published in 2015-2020, full text, articles that fit the topic, there 
Bali Medika Jurnal.

Vol 7 No 2, 2020: 38-49

ISSN : 2615-7047

DOI: https://doi.org/10.36376/bmj.v7i2

are ISSNs, volumes, and number numbers, are numbers progressive muscular relaxation interventions in patients with chronic renal failure. After collecting data, all data were selected according to the inclusion and exclusion criteria, then the study was selected using the PRISMA 2009 flow diagram. Based on the selected 10 article results, progressive muscle relaxation therapy results can improve the sleep quality of chronic renal failure patients. Based on 10 selected articles according to inclusion criteria, Progressive muscle relaxation therapy can applied on kidney failure patients to increase the sleep quality patients.

Keywords: progressive muscle relaxation, sleep quality

\begin{tabular}{ll}
\hline Alamat Korespondensi & $\begin{array}{l}\text { : Universitas Airlangga Kampus C, Jl. Mulyorejo, Mulyorejo, } \\
\text { Surabaya, Kota SBY, Jawa Timur 60115 } \\
\text { Email }\end{array}$ \\
\hline
\end{tabular}

\section{PENDAHULUAN}

Penyakit ginjal kronik (PGK) merupakan suatu kondisi klinis penurunan fungsi ginjal secara ireversibel yang terjadi lebih dari 3 bulan dan diklasifikasikan berdasarkan penyebab, laju flitrasi glomerulus (LFG) dan albuminuria. Klasifikasi pada derajat 5 akan memerlukan terapi pengganti ginjal yang tetap, seperti transplantasi ginjal maupun dialisis. Selain PGK juga menimbulkan komplikasi serius berupa malnutrisi, kelebihan cairan, perdarahan,serositis, depresi, gangguan kognitif, neuropati perifer, infertilitas dan Infeksi. Sebagai pencegahan komplikasi tersebut, diperlukan indikasi dan waktu yang tepat untuk memulai terapi dialisis. Pasien PGK derajat 5, akan dilakukan dialisis apabila terjadi kondisi seperti overload cairan, hiperkalemia, asidosis metabolik, anemia, malnutrisi, adanya gangguan neurologis (Kopple, 2001; Zasra, Harun, \& Azmi, 2018). Pasien dengan penyakit PGK yang sudah mencapai derajat 5 atau tahap akhir akan mengalami gangguan, tidak hanya terbatas pada sistem ginjal, namun tubuh lain juga yang menyebabkan penurunan status kesehatan dan kualitas tidur (Buss, Rock, \& McCarthy, 2014). Tidur dibutuhkan untuk tetap sehat dan memulihkan sistem neurologis, kekebalan, dan muskuloskeletal. Kira-kira, 25-36\% orang dewasa yang sehat menderita gangguan tidur sementara $40-85 \%$ pasien PGK menderita gangguan tidur yang jauh lebih tinggi daripada tingkat prevalensinya pada populasi umum (Amini, Goudarzi, Masoudi, Ahmadi, \& Momeni, 2016). Gangguan tidur mempengaruhi fungsi fisik dan mental individu secara negatif dan menyebabkan disfungsi eksekutif, kognitif, dan memori (Amini dkk., 2016).

Indonesia termasuk negara dengan tingkat penderita PGK yang cukup tinggi. Menurut penelitian Global Burden of Disease (2013), PGK menyumbang 956.200 kematian di seluruh dunia yang naik sekitar 134\% dari tahun 1990 (Naghavi, Wang, \& Lozano, 2015). Asosiasi Nefrologi Indonesia (PERNEFRI) memperkirakan bahwa ada 70.000 orang dengan PGK di Indonesia. Jumlah ini akan terus meningkat sekitar 10\% setiap tahun (PERNEFRI, 2013). Data dari Riskesdas tahun 2018, prevalensi PGK di Indonesia sebesar 0,38\% dari total diagnosa dan proporsi hemodialisis sebesar 19,33\% dari diagnosa (Riskesdas, 2018). Sedangkan di Jawa Timur, prevalensi PGK pada penduduk umur $\geq 15$ tahun sebesar 0,29\% dan proporsi hemodialisis pada penduduk umur $\geq 15$ tahun sebesar 23,14\% (Kementrian Kesehatan RI, 2019). 
Pasien yang menjalani Hemodialisis di Indonesia cenderung meningkat menurut Indonesia Renal Registry (IRR) pada tahun 2017 yang diambil dari 249 unit Hemodialisis, penderita penyakit PGK di Jawa Timur terbanyak nomer 2 setelah Jakarta Barat dengan jumlah 15.605 pasien dengan penyakit PGK yang menjalani Hemodialisis. Data 10 diagnosa penyakit terbanyak di RSUD dr. Soegiri Lamongan, penyakit PGK menunjukkan peningkatan peringkat dari peringkat ke 5 pada tahun 2018 dengan jumlah pasien dari bulan Januari-Desember sebanyak 8.522 pasien menjadi peringkat ke-4 pada tahun 2019 dengan jumlah pasien dari bulan Januari-Oktober sebanyak 11.362 pasien. Hasil survey awal penelitian di ruang hemodialisis RSUD Dr. Soegiri Lamongan didapatkan bahwa pasien yang menjalani terapi hemodialisis ialah pasien rawat jalan dan rawat inap. Kunjungan pasien perhari rata-rata mencapai 30-35 pasien. Sedangkan kunjungan perbulan rata-rata mencapai 260 pasien. Pasien rata-rata menjalani hemodialisis sebanyak 23 kali seminggu selama 5-6 jam per kunjungan. Berdasarkan hasil analisis situasional di ruang hemodialisis RSUD Dr. Soegiri Lamongan, ditemukan masalah banyaknya pasien yang mengeluh tentang kualitas tidurnya yang cenderung menurun.

Kualitas tidur pasien Penyakit PGK yang menjalani hemodialisis dapat dipengaruhi oleh beberapa faktor, antara lain : faktor individu yang meliputi usia, jenis kelamin, pendidikan, dan pekerjaan,faktor eksternal yang meliputi : relaksasi otot, lingkungan dan hubungan sosial,serta faktor medis yaitu: lama menjalani terapi hemodialisis,stadium penyakit dan status fungsional kesehatan. Namun faktor yang cukup mempengaruhi kualitas tidur pasien Penyakit PGK yaitu faktor hipertensi ,cemas dan lama menjalani terapi hemodialisis (Bestari, 2015). Akumulasi toksin uremik, anemia, dan hipoksia malam adalah beberapa penyebab gangguan tidur di antara pasien ini. Beberapa faktor yang efektif adalah kecemasan, kesedihan, kekhawatiran, dan riwayat depresi (Amini dkk., 2016).

Pasien yang menjalani terapi hemodialisis mengalami perubahan fungsi tubuh yang menyebabkan pasien masih mencoba beradaptasi dan menyesuaiakan diri dengan kondisi yang dialaminya (Bestari, 2015). Kepenyakitan fungsi ginjal menyebabkan terjadinya kelelahan dan kelemahan yang disebabkan oleh anemia, sehingga mengalami kondisi fisik yang buruk. Terapi Hemodialisis juga mempengaruhi psikologis pasien. Pasien akan mengalami gangguan proses berpikir dan konsentrasi serta gangguan dalam berhubungan sosial. Semua kondisi tersebut akan menyebabkan menurunnya kualitas hidup pasien PGK yang menjalani terapi hemodialisis (Pasquale dkk., 2019).

Terapi Hemodialisis bagi penderita Penyakit PGK merupakan upaya untuk mencegah kematian atau memperpanjang usia. Namun demikian, hemodialisis tidak dapat menyembuhkan atau memulihkan penyakit ginjal (Muttagin, 2014). Hemodialisis juga tidak mampu mengimbangi hilangnya aktifitas metabolik atau endokrin oleh ginjal dan dampak dari penyakit ginjal serta terapi terhadap kualitas hidup klien. klien harus menjalani dialisis sepanjang hidupnya atau sampai mendapatkan ginjal baru sangat sulit didapatkan karena masih banyak anggapan dari masyarakat bila tidak mempunyai salah satu ginjal akan mempengaruhi kondisi tubuh seseorang. Tindakan tersebut juga masih jarang terjadi di Indonesia (Suhardjono, 2014).

Selama ini kualitas tidur berkaitan erat dengan adanya faktor depresi. Depresi dapat dikurangi dengan melakukan teknik relaksasi. Menurut Setyoadi, relaksasi 
digunakan untuk menenangkan pikiran dan melepaskan ketegangan. Salah satu teknik yang dapat digunakan untuk mengurangi depresi yaitu dengan menggunakan teknik relaksasi otot progresif atau Progresive Muscle Relaxation (PMR). PMR dapat membantu seseorang merasa rileks ketika sedang stres khususnya pada Lansia (Setyoadi \& Kusuma, 2016). Selain itu beberapa literature atau systematic review juga banyak membahas tentang PMR pada bermacam-macam kasus, salah satunya yaitu systematic review tentang relaksasi otot progresif sebagai intervensi penunjang untuk pasien kanker yang menjalani kemoterapi (Pelekasis, Matsouka, \& Koumarianou, 2017). Belum ada literature review yang membahas tentang manfaat PMR dalam meningkatkan kualitas tidur pada satu kasus seperti PGK yang menjalani hemodialisis. Tujuan penulisan ini adalah untuk mengetahui pengaruh teknik relaksasi otot progresif terhadap kualitas tidur pasien penyakit ginjal kronik.

\section{METODE PENELITIAN}

\section{Design dan Metode Pencarian}

Penelitian ini merupakan suatu tinjauan literature (literature review) dengan metode naratif yang mencoba menggali hasil penelitian di Indonesia dan internasional (Nursalam, 2020). Pencarian jurnal pada beberapa database antara lain (Scopus, Science Direct, Google Scholar, dan Pubmed) dengan Keyword; progresive muscle relaxation, muscle relaxation, hemodialysis, chronic kidney disease dan sleep quality. Pencarian jurnal ini dibatasi dalam rentang 5 tahun terakhir mulai Januari 2015 s/d Oktober 2020, fulltext, jurnal yang sesuai dengan topik. Hasil pencarian di tampilkan dalam diagram PRISMA (Gambar 1).

\section{Inklusi dan Ekslusi Kriteria}

Literature review ini diawali dengan pencarian artikel menggunakan PICO framework (Problem/Population = chronic kidney disease / hemodialysis, Intervention $=$ progresive muscle relaxation / muscle relaxation, Comparation $=$ between progresive muscle relaxation, and Outcome = sleep quality/insomnia score)

\section{Skrining}

Pada proses skrining dilakuan seleksi jurnal yang meliputi Bahasa yang digunakan (Bahasa Indonesia atau Bahasa Inggris), memilih judul dan adanya duplikat jurnal serta mengidentifikasi abstrak.

\section{Ekstrasi Data}

Data yang diperoleh dilakukan ekstrasi data dalam bentuk tabel dengan mencantumkan author, nama jurnal, tahun, volume, no, judul, metode, hasil penelitian dan database.

\section{Telaah Kritis}

Proses telaah kritis (critical apprisial) menggunakan Critical Apprisial Skills Programmae untuk menilai kualitas artikel penelitian. 
Bali Medika Jurnal.

Vol 7 No 2, 2020: 38-49

ISSN : 2615-7047

DOI: https://doi.org/10.36376/bmj.v7i2

\section{Analisa Data}

Analisa data menggunakan analysis tematik, dengan langkah-langkah : 1) memahami data, mengidentifikasi kode, 3) mengidentifikasi tema dari kode, 4) penyempurnaan tema, 5) pendefinisian tema.

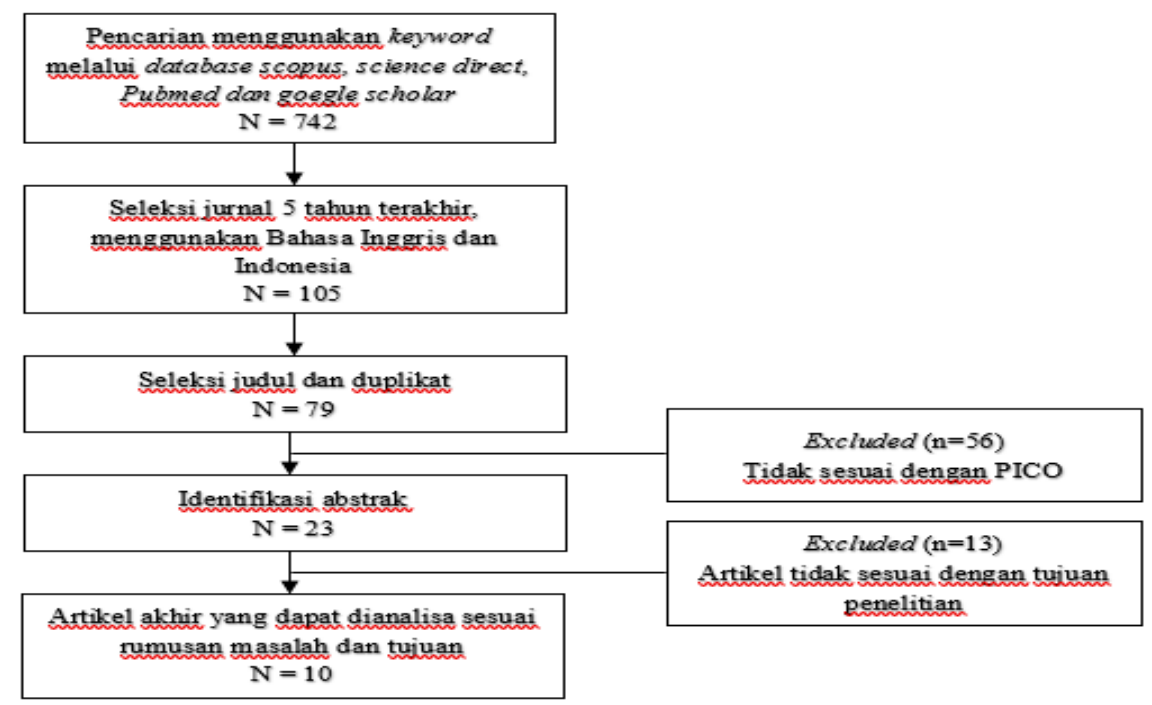

Gambar 1 Diagram Flow Literature Review

\section{HASIL}

\section{HASIL DAN PEMBAHASAN}

Tabel 1 Hasil Pencarian

\begin{tabular}{|c|c|c|c|c|c|c|c|}
\hline $\begin{array}{l}\mathbf{N} \\
\mathbf{0}\end{array}$ & $\begin{array}{l}\text { Author, } \\
\text { Nama } \\
\text { Jurnal }\end{array}$ & Tahun & $\begin{array}{l}\text { Vol, } \\
\text { No }\end{array}$ & Judul & $\begin{array}{c}\text { Metode } \\
\text { (Desain, Sampel, } \\
\text { Variabel, Instrumen, } \\
\text { Analisa) }\end{array}$ & $\begin{array}{c}\text { Hasil } \\
\text { Penelitian }\end{array}$ & Database \\
\hline 1. & $\begin{array}{l}\text { Amini dkk. } \\
\text { International } \\
\text { Journal of } \\
\text { Pharmaceuti } \\
\text { cal and } \\
\text { Clinical } \\
\text { Research }\end{array}$ & 2016 & 8,12 & $\begin{array}{lr}\text { Effect } & \text { of } \\
\text { Progressive muscle } \\
\text { Relaxation and } \\
\text { Aerobic Exercise on } \\
\text { Anxiety, Sleep } \\
\text { Quality, and Fatigue } \\
\text { in Patients with } \\
\text { Chronic Renal } \\
\text { Failure Undergoing } \\
\text { Hemodialysis }\end{array}$ & $\begin{aligned} \mathrm{D} & : \text { Experiment } \\
\mathrm{S}: & 100 \text { responden yang } \\
& \text { dibagi menjadi } 3 \\
& \text { kelompok untuk PMR } \\
& (32 \text { responden), } \\
& \text { Aeorobic } 33 \\
& \text { responden) } \\
& \text { kontrol } \\
& \text { responden) } \\
\mathrm{V}: & \text { PMR, Aerobic, } \\
& \text { Tingkat Kecemasaan } \\
& \text { dan Kualitas tidur. } \\
\mathrm{I}: & \text { Questionnaires of } \\
& \text { anxiety, sleep quality, } \\
& \text { and fatigue } \\
\text { A : } & \text { ANOVA, chi-square } \\
& \text { and t-test }\end{aligned}$ & $\begin{array}{l}\text { Results showed } \\
\text { better function } \\
\text { of PMR } \\
\text { compared to } \\
\text { aerobic exercise } \\
\text { in improving the } \\
\text { symptoms of } \\
\text { anxiety, sleep } \\
\text { disorders, and } \\
\text { fatigue in } \\
\text { hemodialysis } \\
\text { patients. }\end{array}$ & Scopus \\
\hline 2. & $\begin{array}{l}\text { Hasbi } \\
\text { Sutanta }\end{array}$ & 2020 & $11(1)$ & $\begin{array}{l}\text { Pengaruh } \\
\text { Progressive Muscle } \\
\text { Relaxation }\end{array}$ & $\begin{aligned} \text { D : quasi experiment time } \\
\\
\text { series design using }\end{aligned}$ & $\begin{array}{l}\text { Pemberian } \\
\text { terapi non- } \\
\text { farmakologi }\end{array}$ & $\begin{array}{l}\text { Google } \\
\text { scholar }\end{array}$ \\
\hline
\end{tabular}


Bali Medika Jurnal.

Vol 7 No 2, 2020: 38-49

ISSN : 2615-7047

DOI: https://doi.org/10.36376/bmj.v7i2

\begin{tabular}{|c|c|c|c|c|c|c|c|}
\hline $\begin{array}{l}\mathbf{N} \\
\mathbf{0}\end{array}$ & $\begin{array}{l}\text { Author, } \\
\text { Nama } \\
\text { Jurnal }\end{array}$ & Tahun & $\begin{array}{l}\text { Vol, } \\
\text { No }\end{array}$ & Judul & $\begin{array}{c}\text { Metode } \\
\text { (Desain, Sampel, } \\
\text { Variabel, Instrumen, } \\
\text { Analisa) } \\
\end{array}$ & $\begin{array}{c}\text { Hasil } \\
\text { Penelitian }\end{array}$ & Database \\
\hline & $\begin{array}{l}\text { Jurnal } \\
\text { Kesehatan } \\
\text { Samodra } \\
\text { Ilmu }\end{array}$ & & & $\begin{array}{lr}\text { Terhadap } & \text { Kualitas } \\
\text { Tidur } & \text { Pasien } \\
\text { Hemodialisa } & \end{array}$ & $\begin{array}{ll} & \text { pre and post test with } \\
& \text { control group } \\
\mathrm{S} & : 100 \text { responden } \\
\mathrm{V} & : \text { PMR, kualitas tidur } \\
\mathrm{I} & : \text { Kuesioner PSQI } \\
\mathrm{A} & : \text { Chi Square }\end{array}$ & $\begin{array}{l}\text { PMR pada } \\
\text { kelompok } \\
\text { intervensi, ada } \\
\text { pengaruh yang } \\
\text { signifikan }\end{array}$ & \\
\hline 3 & $\begin{array}{l}\text { Sahin \& } \\
\text { Dayapoglu } \\
\text { Complement } \\
\text { ary } \\
\text { Therapies in } \\
\text { Clinical } \\
\text { Practice }\end{array}$ & 2019 & 21,4 & $\begin{array}{l}\text { Effect of } \\
\text { Progressive } \\
\text { relaxation exercise } \\
\text { on fatigue and sleep } \\
\text { quality in patient } \\
\text { withs chronic } \\
\text { obstructive } \\
\text { pulmonaly disease }\end{array}$ & $\begin{array}{ll}\mathrm{D} & : \text { eksperimental } \\
\mathrm{S} & : 45 \text { responden } \\
\mathrm{V} & : \text { PMR, kualitas tidur } \\
\mathrm{I} & : \text { kuesioner PSQI } \\
\mathrm{A} & : \text { wilcoxon }\end{array}$ & $\begin{array}{l}\text { PMR } \\
\text { berpengaruh } \\
\text { terhadap } \\
\text { kualitas tidur } \\
\text { pasien COPD }\end{array}$ & Pubmed \\
\hline 4 & $\begin{array}{l}\text { Putri } \\
\text { Jurnal Ners } \\
\text { Indonesia }\end{array}$ & 2016 & $\begin{array}{l}\text { Vol.6 } \\
\text { No.1, }\end{array}$ & $\begin{array}{l}\text { Pengaruh terapi } \\
\text { relaksasi otot } \\
\text { progresif terhadap } \\
\text { tingkat } \\
\text { Insomnia }\end{array}$ & $\begin{aligned} & \mathrm{D}: \text { Quasi-Experimental, } \\
& \\
& \text { Pretest-Posttest } \\
& \text { Control Study } \\
& \mathrm{S}: 30 \text { responden } \\
& \mathrm{V}: \text { PMR. Tingkat } \\
& \text { insomnia } \\
& \mathrm{I} \quad: \text { Kuesioner Insomnia } \\
& \text { Rating Scale } \\
& \mathrm{A}: \text { Wilcoxon dan mann } \\
& \text { whitney }\end{aligned}$ & $\begin{array}{l}\text { ada perbedaan } \\
\text { skor insomnia } \\
\text { sebelum dan } \\
\text { sesudah } \\
\text { diberikan terapi } \\
\text { relaksasi otot } \\
\text { progresif }\end{array}$ & $\begin{array}{l}\text { Google } \\
\text { scholar }\end{array}$ \\
\hline 5 & $\begin{array}{l}\text { Sinay \& } \\
\text { Lilipory } \\
\text { Moluccas } \\
\text { Helath } \\
\text { Journal.1 }\end{array}$ & 2019 & $\begin{array}{l}\text { Vol } \\
1(1)\end{array}$ & 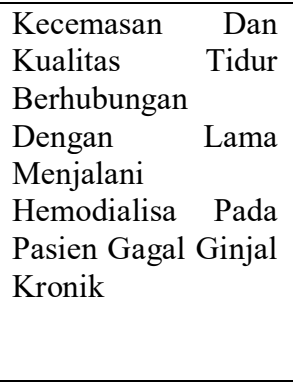 & $\begin{aligned} & \mathrm{D}: \text { Cross sectional } \\
& \mathrm{S}: \text { 43 responden } \\
& \mathrm{V}: \text { lamanya hemodialisa, } \\
& \text { kualitas tidur, } \\
& \text { kecemasan } \\
& \mathrm{I} \quad: \text { Kuesioner PSQI, Zung } \\
& \text { Self- Rating Anxiety } \\
& \text { Scale dan kuesioner } \\
& \text { lama HD } \\
& \mathrm{A} \quad: \text { Chi-Square test } \\
&\end{aligned}$ & $\begin{array}{l}\text { Ada hubungan } \\
\text { antara lama } \\
\text { hemodialysis } \\
\text { dengan kualitas } \\
\text { tidur pasien } \\
\text { PGK }\end{array}$ & $\begin{array}{l}\text { Google } \\
\text { scholar }\end{array}$ \\
\hline 6 & $\begin{array}{l}\text { Ramadhani } \\
\text { Jurnal } \\
\text { Keperawatan } \\
\text { Priority }\end{array}$ & 2016 & $\begin{array}{l}\text { Vol 3, } \\
\text { No. } 1\end{array}$ & 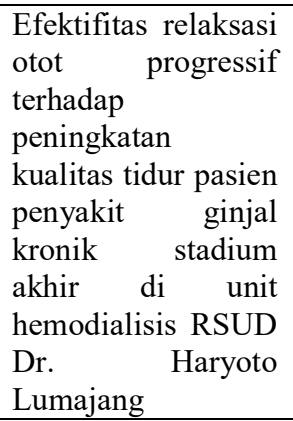 & $\begin{aligned} \mathrm{D}: & \text { Quasi eksperiment } \\
& \text { pre-post test with } \\
& \text { control group } \\
\mathrm{S} & : 30 \text { responden } \\
\mathrm{V}: & \text { PMR, kualitas tidur } \\
\mathrm{I} & : \text { Kuesioner PSQI } \\
\mathrm{A} & : \text { Wilcoxon Dan Mann } \\
& \text { Whitney }\end{aligned}$ & $\begin{array}{l}\text { Relaksasi otot } \\
\text { progressif } \\
\text { Berpengaruh } \\
\text { terhadap } \\
\text { peningkatan } \\
\text { kualitas tidur } \\
\text { pasien penyakit } \\
\text { ginjal kronik } \\
\text { stadium akhir di } \\
\text { unit } \\
\text { hemodialisis } \\
\end{array}$ & $\begin{array}{l}\text { Google } \\
\text { scholar }\end{array}$ \\
\hline 7 & $\begin{array}{l}\text { Ubaidillah \& } \\
\text { Nuriya } \\
\text { Jurnal } \\
\text { Kesehatan } \\
\text { Mahardika }\end{array}$ & 2017 & $\begin{array}{l}\text { Vol.4 } \\
\text { No.1 }\end{array}$ & $\begin{array}{lr}\text { Pengaruh } & \text { Terapi } \\
\text { Musik Suara } & \text { Alam } \\
\text { Terhadap } & \text { Kualitas } \\
\text { Tidur } & \text { Pasien } \\
\text { Penyakit } & \text { Ginjal } \\
\text { Kronik } & \text { Yang } \\
\text { Menjalani } & \\
\end{array}$ & $\begin{aligned} \mathrm{D}: & \text { eksperimental dengan } \\
& \text { One Group Pre and } \\
& \text { Post test. } \\
\mathrm{S}: & 30 \text { responden } \\
\mathrm{V}: & \text { terapi musik suara } \\
& \text { alam, kualitas tidur }\end{aligned}$ & \begin{tabular}{lr}
\multicolumn{2}{|c|}{ Adanya } \\
pengaruh \\
pemberian \\
terapi musik \\
suara \\
terhadap \\
kualitas \\
\end{tabular} & $\begin{array}{l}\text { Google } \\
\text { scholar }\end{array}$ \\
\hline
\end{tabular}


Bali Medika Jurnal.

Vol 7 No 2, 2020: 38-49

ISSN : 2615-7047

DOI: https://doi.org/10.36376/bmj.v7i2

\begin{tabular}{|c|c|c|c|c|c|c|c|}
\hline $\begin{array}{l}\mathbf{N} \\
\mathbf{0}\end{array}$ & $\begin{array}{l}\text { Author, } \\
\text { Nama } \\
\text { Jurnal }\end{array}$ & Tahun & $\begin{array}{l}\text { Vol, } \\
\text { No }\end{array}$ & Judul & $\begin{array}{c}\text { Metode } \\
\text { (Desain, Sampel, } \\
\text { Variabel, Instrumen, } \\
\text { Analisa) }\end{array}$ & $\begin{array}{c}\text { Hasil } \\
\text { Penelitian }\end{array}$ & Database \\
\hline & & & & $\begin{array}{l}\text { Hemodialisis Di } \quad \text { Di } \\
\text { Ruang Rawat Inap } \\
\text { RSD Gunung Jati }\end{array}$ & $\begin{array}{ll}\text { I } & : \text { kuesioner Sleep } \\
& \text { Quality Scale (SQS) } \\
\text { A }: \text { Wilcoxon }\end{array}$ & $\begin{array}{l}\text { pasien penyakit } \\
\text { ginjal kronik } \\
\text { yang menjalani } \\
\text { hemodialisis }\end{array}$ & \\
\hline 8 & $\begin{array}{l}\text { Wulandari \& } \\
\text { Fatimah } \\
\text { Jurnal } \\
\text { Medika } \\
\text { Cendekia }\end{array}$ & 2016 & 3,1 & $\begin{array}{l}\text { Hubungan lamanya } \\
\text { menjalani } \\
\text { hemodialisis dengan } \\
\text { Kualitas tidur } \\
\text { pasien penyakit } \\
\text { ginjal terminal } \\
\text { Di Rumah Sakit } \\
\text { Advent Bandung }\end{array}$ & $\begin{aligned} \mathrm{D} & : \text { Korelasi analitik } \\
& \text { dengan menggunakan } \\
& \text { pendekatan cross } \\
& \text { sectional } \\
\mathrm{S} & : 64 \text { responden } \\
\mathrm{V}: & : \text { Lama menjlani } \\
& \text { hemodialisa, Kualitas } \\
& \text { tidur } \\
\mathrm{I} & : \text { Kuesioner PSQI } \\
& \text { (Pittsburgh Sleep } \\
& \text { Quality Index) } \\
\mathrm{A} & : \text { Korelasi pearson }\end{aligned}$ & $\begin{array}{l}\text { Tidak terdapat } \\
\text { hubungan antara } \\
\text { lama menjalani } \\
\text { hemodialisis } \\
\text { dengan kualitas } \\
\text { tidur }\end{array}$ & $\begin{array}{l}\text { Google } \\
\text { scholar }\end{array}$ \\
\hline 9 & $\begin{array}{l}\text { Rosdiana \& } \\
\text { Cahyati }\end{array}$ & 2018 & $14(2)$ & $\begin{array}{l}\text { Pengaruh Relaksasi } \\
\text { Otot terhadap } \\
\text { Insomnia Pasien } \\
\text { Hemodialisis }\end{array}$ & $\begin{array}{c}\mathrm{D}: \begin{array}{c}\text { Quasi-experiment and } \\
\text { pretest-posttest } \\
\text { design }\end{array} \\
\mathrm{S}: 25 \text { responden } \\
\mathrm{V}: \text { terapi relaksasi otot, } \\
\quad \text { insomnia } \\
\mathrm{I} \quad: \text { lembar observasi } \\
\text { insomnia } \\
\mathrm{A}: \text { uji paired t-test }\end{array}$ & $\begin{array}{l}\text { ada perbedaan } \\
\text { yang signifikan } \\
\text { rata-rata skor } \\
\text { insomnia antara } \\
\text { sebelum dan } \\
\text { setelah } \\
\text { dilakukan } \\
\text { intervensi }\end{array}$ & $\begin{array}{l}\text { Google } \\
\text { scholar }\end{array}$ \\
\hline 10 & $\begin{array}{l}\text { Chao-Ying, } \\
\text { Chou, Lin, } \\
\text { \& Huang } \\
\text { Journal of } \\
\text { the } \\
\text { Formosan } \\
\text { Medical } \\
\text { Association }\end{array}$ & 2019 & 118,6 & $\begin{array}{l}\text { Sleep and } \\
\text { emotional } \\
\text { disturbance in } \\
\text { patients } \\
\text { with non-dialysis } \\
\text { chronic kidney } \\
\text { disease }\end{array}$ & 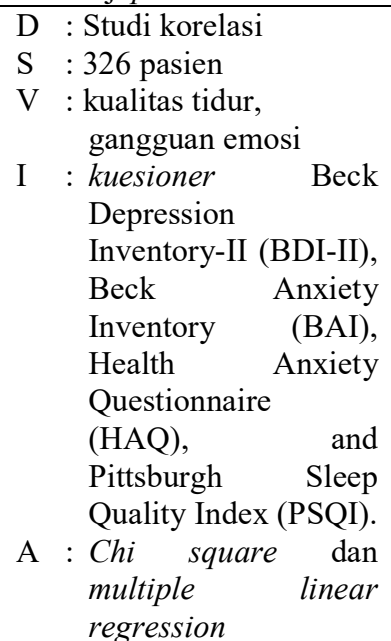 & $\begin{array}{l}\text { Clinically } \\
\text { significant } \\
\text { depression, } \\
\text { anxiety, health } \\
\text { anxiety, and } \\
\text { sleep } \\
\text { disturbance } \\
\text { were found in } \\
3.1 \% \text {, } 3.1 \% \text {, } \\
18 \% \text {, and } 36.2 \% \\
\text { of the patients. }\end{array}$ & $\begin{array}{l}\text { Science } \\
\text { Direct }\end{array}$ \\
\hline
\end{tabular}

\section{PEMBAHASAN}

Berdasarkan hasil pencarian jurnal penelitian terdapat 10 artikel yang terpilih berdasarkan kriteria inklusi dan eksklusi. Dari 10 artikel tersebut terdapat 8 artikel menggunakan metode Quasi-experiment yang meneliti tentang tentang pengaruh relaksasi otot progressif terhadap kualitas tidur dan 2 artikel menggunakan metode korelasi yang meneliti tentang kualitas tidur pasien PGK menjalani hemodialysis.

\section{Kualitas Tidur Pasien PGK yang menjalani Hemodialisis}


Lamanya menjalani hemodialysis tidak selalu mempengaruhi kualitas tidur pasien PGK. Sebagian besar pasien PGK yang menjalani hemodialisa mengalami kualitas tidur yang buruk. Kualitas tidur yang buruk terjadi pada pasien PGK yang menjalani hemodialysis lebih dari 2 tahun(Wulandari \& Fatimah, 2016). Namun ada juga pasien PGK yang menjalani hemodialysis $>6$ bulan yang mengalami kualitas tidur yang buruk (Sinay \& Lilipory, 2019).

Lamanya menjalani hemodialisis yang dirasakan pasien dapat mempengaruhi kualitas tidur karena kualitas tidur yang yang tidak baik memberikan dampak yang negative pada fisik dan mental serta dapat mengarah pada penurunan penampilan pasien seperti mudah marah, bingung, cemas dan penurunan konsentrasi. Karena itu kualitas tidur yang adekuat merupakan suatu hal yang harus dipatuhi oleh pasien yang menjalani hemodialisa (Sinay \& Lilipory, 2019).

Tidur adalah perubahan status kesadaran seseorang pada waktu dan periode tertentu. Tidur merupakan komponen dasaras manusia yang harus dipenuhi untuk membantu pemulihan kondisi pasien. Durasi tidur yang cukup dan adekuat akan memperoleh kualitas tidur yang baik. Perubahan kualitas tidur dapat terjadi pada siapapun, termasuk pasien PGK yang menjalani hemodialysis (Sinay \& Lilipory, 2019).

Gangguan tidur pada pasien PGK yang mendapatkan terapi hemodialysis terjadi karena beberapa faktor, yaitu 1) faktor psikologis : kondisi bingung, depresi atau paranoid akan apayang terjadi pada dirinya, 2) faktor fisik : overload cairan, kadar ureum dan creatinin dalam darah yang tinggi, anemia, 3) faktor lingkungan : semua kondisi ini dapat menimbukan masalah psikologi dan stress yang memicu munculnya gangguan tidur (Hmwe, Subramanian, Tan, \& Chong, 2015).

\section{Terapi Relaksasi Otot Progresif dalam Meningkatkan Kualitas Tidur Pasien PGK}

Dari 8 jurnal tentang terapi relaksasi otot progreesif semuanya menerangkan bahwa terapi relaksasi otot progressif berpengaruh terhadap kualitas tidur. Terapi Relaksasi Otot Progresif merupakan satu teknik dalam terapi perilaku untuk mengurangi ketegangan dan kecemasan. Teknik ini dapat digunakan oleh pasien tanpa bantuan terapis dan mereka dapat melakukannya untuk mengurangi ketegangan dan kecemasan yang dialami sehari - hari dirumah. Relaksasi juga merupakan teknik yang dapat digunakan semua orang untuk menciptakan mekanisme batin dalam diri seseorang dengan membentuk pribadi yang baik, menghilangkan berbagai bentuk pikiran yang kacau akibat ketidak berdayaan seseorang dalam mengendalikan ego yang dimilikinya, mempermudah seseorang mengontrol diri, menyelamatkan jiwa dan memberi kesehatan bagi tubuh (Soewondo, 2017).

Berdasarkan penelitian yang dilakukan oleh Abudi (2016), bahwa ada pengaruh teknik relaksasi otot progresif terhadap kualitas tidur pada pasien penyakit ginjal kronik. Penelitian ini diperkuat oleh Amini dkk., (2016) menunjukkan hasil yang sama bahwa teknik relaksasi otot progresif berpengaruh terhadap kualitas tidur pasien penyakit ginjal kronik, selain itu juga relaksasi otot progressif juga berpengaruh terhadap tingkat kecemasan dan tingkat stress. Relaksasi otot progressif dapat berpengaruh terhadap skor kualitas tidur pasien penyakit ginjal kronik yang dilakukan intervensi selama 4 minggu dengan frekuensi 2 kali sehari (Putri, 2015; Sari, 2017). 
Menurut Yang, Ho, Chen, \& Chien, (2012), gangguan tidur diduga sebagai akibat dari peningkatan aktivitas Reticullar Activating System (RAS), dopamine dan noreprineprine atau disebabkan penurunan aktivitas sistem batang otak. Dalam penelitiannya, Jacobson berkesimpulan bahwa adanya ketegangan menyebabkan serabut-serabut otot berkontraksi. Jacobson meyakini bahwa otot yang tegang berhubungan dengan jiwa yang tegang dan fisik yang rileks akan disertai dengan mental yang rileks pula (Soewondo, 2017). Dalam latihan relaksasi otot progresif, gerakan menegangkan sekumpulan otot dan kemudian melemaskannya serta membedakan sensasi tegang dan rileks, seseorang tersebut dapat menghilangkan kontraksi otot untuk selanjutnya akan mengalami perasaan rileks dan nyaman (Zarcone, Falke, \& Anlar, 2010).

Selain terapi relaksasi otot profressif, terapi non farmakologi lain yang dapat digunakan untuk meningkatkan kualitas tidur paien penyakit ginjal kronik adalah terapi musik. Penelitian yang dilakukan Setyoadi \& Kusuma (2016) bahwa musik dengan relaksasi otot progresif dapat meningkatkan kualitas tidur. Dimana sebanyak 17 orang (100\%) mengalami kualitas tidur buruk sebelum diberikan terapi realaksasi otot progresif dengan musik. Dan sesudah diberikan terapi sebanyak 12 responden $(71 \%)$ mengalami kuaitas tidur. Dengan hasil $p=0,000$ yang menunjukan ada hubungan signifikan relaksasi progresif dengan musik terhadap kualitas tidur. Terapi musik yang dapat digunakan untuk mengatasi gangguan tidur pasien penyakit ginjal kronik adalah terapi musik alam dan terapi musik instrumental.

Pasien penyakit ginjal kronik tidak bisa disembuhkan sehingga kualitas hidup pasien menurun, penurunan kualitas hidup pada pasien penyakit ginjal yang menjalani terapi hemodialisa akan menyebabkan komplikasi yang berkepanjangan, penurunan produktivitas dan perubahan mood negatif. Persepsi penderita tentang kualitas hidupnya yang semakin memburuk dapat memperberat kondisi penyakitnya (Togatorop, 2011). Untuk itu dukungan keluarga sangat diperlukan bagi pasien penyakit ginjal kronik, ada beberapa faktor yang berpengaruh terhadap beban pengasuhan pada pasien penyakit ginjal kronik yang menjalani hemodialisa seperti yang disebutkan dalam penelitian Faridah dkk., (2020), yaitu umur, jenis kelamin, tingkat pendidikan, pendapatan dan lama merawat pasien.

Berdasarkan penelitian yang telah dilakukan maka dapat disimpulkan bahwa terapi relaksasi otot progresif, terapi musik alam, terapi musik instrumental dan terapi supportif dapat meningkatkan kualitas tidur pasien penyakit ginjal kronik yang menjalani hemodialisa, untuk itu diharapkan bahwa terapi-terapi tersebut dapat diterapkan pada pasien penyakit ginjal kronik sehingga nantinya kualitas tidur pasien penyakit ginjal kronik dapat ditingkatkan. Karena dengan latihan relaksasi otot progresif terdapat gerakan menegangkan sekumpulan otot dan kemudian melemaskannya serta membedakan sensasi tegang dan rileks, seseorang tersebut dapat menghilangkan kontraksi otot untuk selanjutnya akan mengalami perasaan rileks dan nyaman.

\section{SIMPULAN DAN SARAN}

Berdasarkan hasil penelitian dari 10 artikel tersebut menyatakan bahwa terapi relaksasi otot progresif dapat meningkatkan kualitas tidur pasien penyakit ginjal kronik. Selain berpengaruh terhadap kualitas tidur, terapi relaksasi otot progresif juga mampu memperbaiki gejala kecemasan dan kelelahan. Selain diberikan terapi 
relaksasi otot progresif, pemberian terapi musik suara alam juga berpengaruh terhadap kualitas tidur pasien penyakit ginjal kronik yang menjalani hemodialisis. Terdapat pula hasil penelitian yang berlawanan tentang hubungan lama menjalani hemodialisis dengan kualitas hidup. Diharapkan dengan adanya kajian literature review ini bisa jadikan bahan bagi perawat dalam mengatasi gangguan tidur yang dialami pada pasien penyakit ginjal kronik.

\section{DAFTAR PUSTAKA}

Abudi, E. N. M. (2016). Pengaruh Teknik Relaksasi Otot Progresif Terhadap Kualitas Tidur Pada Pasien Penyakit Ginjal Kronik di Ruang Hemodialisa RSUD Prof. Dr. H. Aloei Saboe Kota Gorontalo. Skripsi. Universitas Negeri Gorontalo.

Amini, E., Goudarzi, I., Masoudi, R., Ahmadi, A., \& Momeni, A. (2016). Effect of Progressive muscle Relaxation and Aerobic Exercise on Anxiety, Sleep Quality, and Fatigue in Patients with Chronic Renal Failure Undergoing Hemodialysis. International Journal of Pharmaceutical and Clinical Research 2016, 8(12), 1634-1639.

Bestari. (2015). Faktor vang berhubungan dengan kualitas tidur pasien penyakit ginjal kronik yang menjalani hemodialisis.

Buss, M. K., Rock, L. K., \& McCarthy, E. P. (2014). Understanding palliative care and hospice: a review for primary care providers. Mayo Clinic Proceedings. Vol. 92. No. 2. Elsevier.

Chao-Ying, P., Chou, T.-H., Lin, Y.-H., \& Huang, W.-L. (2019). Sleep and emotional disturbance in patients with non-dialysis chronic kidney disease. Journal of the Formosan Medical Association, 118(6), 986-994.

Faridah, V. N., Nursalam, Agustini, N. L. P. I. B., Lestari, T. P., Suratmi, Juanita, F., \& Aris, A. (2020). Determinants of the Caregiver Burden of CKD Patients Undergoing Hemodialysis. International Journal of Psychosocial Rehabilitation, 24(7).

Hasbi, H. Al, \& Sutanta. (2020). Pengaruh Progressive Muscle Relaxation Terhadap Kualitas Tidur Pasien Hemodialisa. Jurnal Kesehatan Samodra Ilmu, 11(1).

Hmwe, N. T. T., Subramanian, P., Tan, L. P., \& Chong, W. K. (2015). The effects of acupressure on depression, anxiety and stress in patients with hemodialysis: A randomized controlled trial. International journal of nursing studies, 52(2), 509-518.

Kementrian Kesehatan RI. (2019). Laporan Nasional Riskesdas 2018. Jakarta: Badan Penelitian dan Pengembangan Kesehatan.

Kopple, J. D. (2001). National kidney foundation K/DOQI clinical practice guidelines for nutrition in chronic renal failure. American journal of kidney diseases, 37(1), S66-S70.

Muttagin, A. (2014). Asuhan Keperawatan Gangguan Sistem Perkemihan. Jakarta: Salemba Medika.

Naghavi, M., Wang, H., \& Lozano, R. (2015). GBD 2013 Mortality and Causes of Death Collaborators. Global, regional, and national age-sex specific all-cause and cause-specific mortality for 240 causes of death, 1990-2013: a systematic analysis for the Global Burden of Disease Study 2013. Lancet, 385(9963), 
$117-171$.

Nursalam. (2020). Penulisan Literature Review dan Systematic Review Pada Pendidikan Keperawatan/Kesehatan (Contoh). Surabaya: Fakultas Keperawatan Universitas Airlangga.

Pasquale, N. De, Cabacungan, A., Ephraim, P. L., Lewis-Boyér, L. P., Powe, N. R., $\&$ Boulware, L. E. (2019). Family members' experiences with dialysis and kidney transplantation. Kidney Medicine, 1(4), 171-179.

Pelekasis, P., Matsouka, I., \& Koumarianou, A. (2017). Progressive muscle relaxation as a supportive intervention for cancer patients undergoing chemotherapy: A systematic review. Palliative and Supportive Care, 15(4), 465-473.

PERNEFRI. (2013). Simposium Peningkatan Pelayanan Hemodialisis, Penyakit Ginjal dan Aplikasi Indonesian Renal Registry Joglosemar 2012. Yogyakarta: PERNEFRI.

Putri, B. (2015). Pengaruh teknik relaksasi otot progressif terhadap skor kualitas tidur pasien penyakit ginjal yang menjalani terapi hemodialisa Di RSUP Dr. Djamil Padang. Skripsi. Universitas Andalas.

Putri, D. (2016). Pengaruh terapi relaksasi otot progresif terhadap tingkat Insomnia. Jurnal Ners Indonesia, 6(1).

Ramadhani, F. (2016). Efektifitas relaksasi otot progressif terhadap peningkatan kualitas tidur pasien penyakit ginjal kronik stadium akhir di unit hemodialisis RSUD Dr. Haryoto Lumajang. Jurnal Keperawatan Priority, 3(1).

Riskesdas. (2018). Laporan Nasional RISKESDAS 2018. Jakarta: Kementrian Kesehatan RI.

Rosdiana, I., \& Cahyati, A. (2018). Pengaruh Relaksasi Otot terhadap Insomnia Pasien Hemodialisis. Media Informasi, 14(2), 118-123.

Sahin, Z. A., \& Dayapoglu, N. (2019). Effect of progressive relaxation exercises on fatigue and sleep quality in patients with chronic obstructive pulmonary disease (COPD). Complementary Therapies in Clinical Practice, 31, 389.

Sari, D. R. (2017). Hubungan Pengetahuan Petugas Kesehatan dengan Perilaku Five Moment for Hand Hygiene di Rumah Sakit PKU Muhammadiyah Gamping. Universitas Aisyiyah Yogyakarta.

Setyoadi, R. L., \& Kusuma, N. (2016). Pengaruh Relaksasi Otot Progresif Dengan Musik Terhadap Kualitas Tidur Lansia Di Posyandu Lansia 'Anjasmoro' Kelurahan Sukorame Kediri. Majalah Kesehatan, 3(1), 18-24.

Sinay, J. M., \& Lilipory, M. (2019). Kecemasan Dan Kualitas Tidur Berhubungan Dengan Lama Menjalani Hemodialisa Pada Pasien Gagal Ginjal Kronik. Moluccas Helath Journal, 1(1).

Soewondo, S. (2017). Stres, manajemen stres, dan relaksasi progresif. Depok: LPSP3 UI.

Suhardjono. (2014). Buku Ajar limu Penyakit Dalam Hemodialisis; Prinsip Dasar dan Pemakaian Kliniknya. Jakarta: Interna Publishing.

Togatorop, L. (2011). Hubungan Perawat Pelaksana Dengan Kualitas Hidup Pasien Penyakit Ginjal Kronik Yang Menjalani Hemodialisa. Skripsi. Universitas Sumatra Utara.

Ubaidillah, A., \& Nuriya, V. N. (2017). Pengaruh Terapi Musik Suara Alam Terhadap Kualitas Tidur Pasien Penyakit Ginjal Kronik Yang Menjalani Hemodialisis Di Ruang Rawat Inap RSD Gunung Jati. Jurnal Kesehatan 
Bali Medika Jurnal.

Vol 7 No 2, 2020: 38-49

ISSN : 2615-7047

DOI: https://doi.org/10.36376/bmj.v7i2

Mahardika, 4(1).

Wulandari, I. S. M., \& Fatimah, S. (2016). Hubungan lamanya menjalani hemodialisis dengan Kualitas tidur pasien penyakit ginjal terminal di rumah sakit advent Bandung. Jurnal Medika Cendekia, 3(1).

Yang, P.-Y., Ho, K.-H., Chen, H.-C., \& Chien, M.-Y. (2012). Exercise training improves sleep quality in middle-aged and older adults with sleep problems: a systematic review. Journal of Physiotherapy, 58(3).

Zarcone, P., Falke, R., \& Anlar, O. (2010). Effect of progressive relaxation on sleep quality. Neurosci, 63, 221-222.

Zasra, R., Harun, H., \& Azmi, S. (2018). Indikasi dan Persiapan Hemodialis Pada Penyakit Ginjal Kronis. Jurnal Kesehatan Andalas, 7, 183-186. 